\title{
Comparison and validation of satellite-derived digital surface/elevation models over India
}

R. Goyal ${ }^{1,2, *}$, W.E. Featherstone ${ }^{2,1}$, O. Dikshit ${ }^{1}$, B. Nagarajan ${ }^{1}$

1) Department of Civil Engineering, Indian Institute of Technology Kanpur, Kanpur 208016, India; rupeshg@iitk.ac.in, onkar@iitk.ac.in, nagaraj@iitk.ac.in

2) School of Earth and Planetary Sciences, Curtin University of Technology, GPO Box U1987, Perth WA 6845, Australia; w.featherstone@curtin.edu.au

ORCIDs: R. Goyal (0000-0002-2178-3265); W.E. Featherstone (0000-0001-9644-4535); O. Dikshit (00000003-3213-8218)

\begin{abstract}
India presents among the world's most topographically complex geomorphologies, with land elevations ranging from $-2 \mathrm{~m}$ to $+8586 \mathrm{~m}$ and terrain gradients sometimes exceeding $45^{\circ}$. Here we present an evaluation of four freely available digital surface models (DSMs) on a model-to-model basis, as well as a validation using independent ground-truth data from levelled benchmarks in India. The DSMs tested comprise SRTM1", SRTM3", ASTER1" and Cartodem1" [an India-only model]. Along with these four DSMs, the MERIT3" digital elevation model (DEM) is also tested with the ground-truth data. Our results for India indicate some mismatch of these DEMs/DSMs from their claimed accuracies/precisions. All DSMs/DEMs (except for ASTER) have $>90 \%$ of pixels satisfying $\pm 16 \mathrm{~m}$ at the one-sigma level, but only in the low-lying $(<500 \mathrm{~m})$ parts of India, i.e., the Gangetic plains and the Thar desert.
\end{abstract}

Key words: vertical accuracy/precision assessment, digital surface models, digital elevation models, India

\section{Introduction}

A digital surface model (DSM) is a representation of the shape of the Earth's surface. Several near-global DSMs have been produced from satellite-borne platforms from either radar, e.g., SRTM (Farr et al. 2007) or stereoscopic optical imagery, e.g., ASTER (Meyer et al. 2011). We deliberately distinguish between a DSM and a digital elevation model (DEM) also sometimes known as a digital terrain model (DTM), where a DEM/DTM represents the solid topographic surface, whereas a DSM represents the surface sensed, which includes the height of vegetation canopy and man-made structures (cf. Hirt 2014). A satellite-derived DSM should be treated for speckle noise (Gallant 2011) and stripe noise (Tarekegn and Sayama 2013), and then it can be converted to a DEM by accounting for absolute biases (Crippen et al. 2016) and tree-height biases (O'Loughlin et al. 2016). Yamazaki et al. (2017) have treated the SRTM v2.1 DSM for all these four sources to produce the MERIT3" DEM. DEMs and DSMs should also be checked for other artefacts such as spikes, pits and line defects (e.g., Hirt 2018).

DEMs and DSMs are used synonymously in several applications such as mapping soil and vegetation (e.g., Dobos and Hengl 2009; Cavazzi et al. 2013), studying natural hazards (e.g., Gruber et al. 2009; Demirkesen 2012), catchment geomorphology and hydrology (e.g., Barnes et al. 2014; Zhao et al. 2019), watershed modelling (e.g., Park et al. 2011; Li et al. 2019), floodplain mapping (e.g., Jafarzadegan and Merwade 2017; Nardi et al. 2019), weather and flood forecasting (e.g., Truhetz 2010), and gravity-field forward modelling (e.g., Banerjee and Gupta 1977; Forsberg 1984). The exemplar citations made above are not exhaustive because the literature on applications is so vast. However, researchers have started analysing the effect of using a DSM and not the 'required' DEM for their respective applications, such as done by Yang et al. (2019) for gravity forward modelling. In this paper, we have used the terms DEM or DSM separately in many instances so as to reinforce the difference between the two. 
Table 1: Previous DEM/DSM assessment studies in India.

\begin{tabular}{|c|c|c|}
\hline Citation & Data Used & Remark \\
\hline $\begin{array}{l}\text { Muralikrishnan et } \\
\text { al. (2013) }\end{array}$ & $\begin{array}{l}\text { SRTM1", ASTER1", } \\
\text { Cartodem1", three } \\
\text { different regions in } \\
\text { India }\end{array}$ & $\begin{array}{l}\text { Absolute and relative evaluation of Cartodem was done w.r.t to ground } \\
\text { control points (GCPs) and SRTM/ASTER, respectively. It was } \\
\text { concluded that in a flat region, height accuracy of Cartodem is better } \\
\text { than } \pm 4 \mathrm{~m} \text { and for the hilly regions, the error reaches around } \pm 8 \mathrm{~m} \text {. } \\
\text { Also, it was established that more than } 90 \% \text { of the SRTM and } \\
\text { Cartodem difference points are within } 8 \mathrm{~m} \text {. The absolute and relative } \\
\text { vertical accuracies of Cartodem were stated to be } 8 \mathrm{~m} \text { at } 90 \% \\
\text { confidence and } 5 \mathrm{~m} \text { at } 68 \% \text { confidence. }\end{array}$ \\
\hline $\begin{array}{l}\text { Srivastava \& } \\
\text { Mondal (2012) }\end{array}$ & $\begin{array}{l}\text { SRTM3", ASTER1"' } \\
\text { and Survey of India } \\
\text { (SoI) } 1: 50,000 \\
\text { topographic map, 3' } \mathrm{x} \\
\text { 3' area, elevation } \\
\text { range: } 82 \mathrm{~m} \text { to } 100 \mathrm{~m}\end{array}$ & $\begin{array}{l}\text { Only three points in the study area were extracted from the topographic } \\
\text { maps with the height values of } 82 \mathrm{~m}, 90 \mathrm{~m} \text { and } 100 \mathrm{~m} \text {. DEMs/DSMs } \\
\text { were evaluated based on these three points. No statistical information } \\
\text { was provided. ASTER was concluded to be more precise compared to } \\
\text { SRTM, but this has to be heavily qualified because of the small sample } \\
\text { size used. }\end{array}$ \\
\hline $\begin{array}{l}\text { Bothale \& Pandey } \\
\text { (2013) }\end{array}$ & $\begin{array}{l}\text { SRTM3", ASTER1", } \\
\text { Cartodem }(10 \mathrm{~m}, 20 \mathrm{~m} \\
30 \mathrm{~m}, 40 \mathrm{~m}, 50 \mathrm{~m}, 90 \\
\mathrm{~m}), 0.45^{\circ} \times 0.3^{\circ} \text { area, } \\
\text { SoI } 1: 50,000 \\
\text { topographic map }\end{array}$ & $\begin{array}{l}\text { This DSM evaluation methodology mentioned all the heights relative } \\
\text { to WGS } 84 \text { ellipsoid. However, the ground-truth was extracted from } \\
\text { SoI maps which provide heights above local Mean Sea Level (MSL). } \\
\text { No information on the conversion of ellipsoidal heights to physical } \\
\text { heights or vice-versa was provided. RMSEs of ASTER and SRTM } \\
\text { were reported to be significantly high compared to the Cartodem (all } \\
\text { resolutions). } 90 \% \text { of Cartodem and SRTM difference points were } \\
\text { reported to be within } \pm 8 \text { m as also claimed by Muralikrishnan et al. } \\
\text { (2013). }\end{array}$ \\
\hline $\begin{array}{l}\text { Thomas et al. } \\
\text { (2015) }\end{array}$ & $\begin{array}{l}\text { SRTM3", ASTER1", } \\
\text { GMTED250m, DEM } \\
\text { generated using SoI } \\
1: 50,000 \text { topographic } \\
\text { map, } 0.22^{\circ} \times 0.42^{\circ} \\
\text { area, } 55 \text { spot heights. }\end{array}$ & $\begin{array}{l}\text { The study involved evaluation based on spot heights extracted from the } \\
\text { topographic map. The comparison concluded that SRTM (RMSE }= \\
17.05 \mathrm{~m} \text { ) is more precise than ASTER (RMSE }=24.09 \mathrm{~m}) \text { and } \\
\text { GMTED (RMSE }=32.85 \mathrm{~m}) \text {. The RMSE of the topographic map } \\
\text { derived DEM was } 3.17 \mathrm{~m} \text {. }\end{array}$ \\
\hline $\begin{array}{l}\text { Krishnan et al. } \\
(2016)\end{array}$ & $\begin{array}{l}\text { SRTM, ASTER, } \\
\text { Cartodem and DEM } \\
\text { generated using } \\
\text { Cartosat imagery, } 0.33^{\circ} \\
\text { x } 0.25^{\circ} \text { area. } 25 \text { DGPS } \\
\text { surveyed GCPs }\end{array}$ & $\begin{array}{l}\text { The analysis reported the RMSEs for ASTER and SRTM to be } 8.13 \mathrm{~m} \\
\text { and } 8.98 \mathrm{~m} \text {, respectively. RMSE for Cartodem was } 60.94 \mathrm{~m} \text {, while for } \\
\text { the generated DEM the value was } 36.79 \mathrm{~m} \text {. Though, the study } \\
\text { discussed the generation of DSM using Cartosat imagery, we note } \\
\text { some complications in the conversion of ellipsoidal heights to physical } \\
\text { heights. This might be a reason for the large RMSE observed for } \\
\text { Cartodem. }\end{array}$ \\
\hline $\begin{array}{l}\text { Yadav \& Indu } \\
(2016)\end{array}$ & $\begin{array}{l}\text { SRTM1", ASTER1", } \\
\text { Cartodem, SoI } \\
1: 250,000 \text { topographic } \\
\text { map, } 4^{\circ} \times 2^{\circ} \text { area, } \\
\text { elevation range: } 800 \mathrm{~m} \\
\text { to } 2000 \mathrm{~m}\end{array}$ & $\begin{array}{l}\text { Reported RMSEs for ASTER, SRTM and Cartodem were } 74.78 \mathrm{~m} \text {, } \\
69.18 \mathrm{~m} \text { and } 69.38 \mathrm{~m} \text {, respectively. An explanation was missing for } \\
\text { using a topographic map of } 1: 250,000 \text { scale, wherein plotting error is } \\
62.5 \mathrm{~m} \text { i.e. the extracted point derived from a map, can indicate any } \\
\text { point lying in an area of } 62.5 \mathrm{~m} \times 62.5 \mathrm{~m} \text {. }\end{array}$ \\
\hline Mukul et al. (2017) & $\begin{array}{l}\text { SRTM1"X and C } \\
\text { band, SRTM3" C band, } \\
221 \text { GPS points }\end{array}$ & $\begin{array}{l}\text { An investigation involving only SRTM DSMs was done, wherein the } \\
\text { claimed accuracy of } 16 \mathrm{~m} \text { at } 90 \% \text { confidence was also cross verified. } \\
\text { The C band SRTM data was reduced to WGS } 84 \text { datum by using geoid } \\
\text { values from EGM96 (Lemoine et al. 1996). The study concluded that } \\
\text { without any filtering of the DSMs, only X band SRTM1" has an } \\
\text { RMSE of } 9.18 \mathrm{~m} \text {. The 1" and 3" C band DSMs have RMSE of } 23.53 \mathrm{~m} \\
\text { and } 47.24 \mathrm{~m} \text {, respectively. Outlier and void filtering techniques were } \\
\text { also discussed, after which the RMSEs of 1"X band, 1" C band and 3" } \\
\text { C band reduced to } 8.00 \mathrm{~m}, 10.14 \mathrm{~m} \text { and } 14.38 \mathrm{~m} \text {, respectively. }\end{array}$ \\
\hline Rawat et al. (2019) & $\begin{array}{l}\text { SRTM3", ASTER1", } \\
\text { Cartodem1", } 20 \text { DGPS } \\
\text { surveyed GCPs, } \\
\text { Shahjahanpur district }\end{array}$ & $\begin{array}{l}\text { For the } 20 \text { points, heights were extracted from the three DSMs and } \\
\text { were compared against each other. RMSE values for Cartodem- } \\
\text { ASTER }=137.65 \mathrm{~m} \text {, Cartodem-SRTM }=186.65 \mathrm{~m} \text { and ASTER-SRTM } \\
=50.87 \mathrm{~m} .\end{array}$ \\
\hline
\end{tabular}




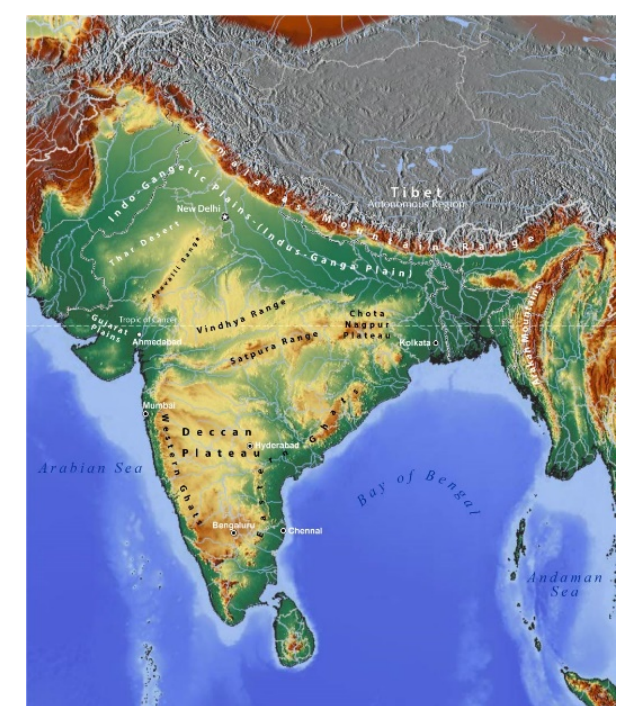

Figure 1: Physical features of Indian topography.

(Source: https://www.nationsonline.org/oneworld/map/India-Administrative-map.htm)

Since the procedures for generating DSMs vary due to the different types of datasets or sensors involved (Gesch 2012), one should not generally rely on freely available DSMs without appreciating the accuracy/precision required for the application at hand. Rodriguez et al. (2005) and Farr et al. (2007) provide global accuracy analyses of the SRTM DSMs. Meyer et al. (2011) conduct a global accuracy assessment for ASTER. DEM/DSM assessments have also been made on regional scales (e.g., Nikolakopoulos et al. 2006; Racoviteanu et al. 2007; Hayakawa et al. 2008; Chirico et al. 2012; Gesch et al. 2012; Suwandana et al. 2012; Li et al. 2013; Jing et al. 2014; Purinton and Bookhagen 2017; Elkhrachy 2018; Zhang et al. 2019; Hawker et al. 2019) and country-wide scales (e.g., Hilton et al. 2003; Denker 2005; Hirt et al. 2010; Athmania and Achour 2014; Gesch et al. 2014; Ioannidis et al. 2014; Rexer and Hirt 2014, Varga and Bašić 2015). We attempt to add to this body of literature by providing results from the whole country of India, where the topographic morphology is quite diverse: Heights range from $-2 \mathrm{~m}$ to $+8586 \mathrm{~m}$ and terrain gradients sometimes exceed $45^{\circ}$ ( $2.4 \%$ of the total cells at 1 "x 1 " resolution, i.e., $3,748,582,709$ cells). While studies have been conducted on the comparison and validation of different DEMs/DSMs in smaller regions of India (see Table 1), none are countrywide as we attempt in this investigation.

India hosts part of the Himalaya Mountain Ranges in the north, the Gangetic Plain in the centre, the Aravalli and Vindhya Mountain ranges, the Western and Eastern Ghats, the Deccan Plateau, the Thar desert and a long peninsular coastline (Figure 1). Thus, accuracy/precision assessment of DEMs/DSMs for India is of utility, especially when researchers are already using freely available DSMs for applications in India such as, geology and geomorphometric analysis (e.g., Selvan et al. 2011; Gayen et al. 2013), watershed delineation (e.g., Sreedevi et al. 2009; Ahmed et al. 2010; Gopinath et al. 2014), identifying potential water harvesting sites near rivers (e.g., Ramakrishnan et al. 2009), assessment of tsunami risk (e.g., Kumar et al. 2007), hydrographic modelling (e.g., Patro et al. 2009), and estimating glacial mass balance (e.g., Berthier et al. 2007).

Unlike some of the previous studies in India (Table 1), and indeed elsewhere, we have deliberately preserved the respective meanings of DEM versus DSM throughout our analyses. Strictly, DEMs and DSMs should never be compared until one is transformed to the other (Yamazaki et al. 2017). In the study presented here, four freely available DSMs for India (SRTM1", SRTM3", ASTER1" and Cartodem1" [an India-only model; see below]) are inter-compared on a model-to-model basis. They are also "validated" with independent ground-truth height data provided by the Survey of India (SoI) to which National Aeronautics and Space Administration (NASA) canopy height information (Simard et al. 2011) has been added to give point DSM heights (Section \#). Along with these four DSMs, the MERIT3" DEM is also validated with the same groundtruth data, without canopy heights applied. MERIT3" was not included in the model-to-model DSM comparison. In India only, the national Cartodem DSM, derived from the Cartosat mission using stereoscopic optical imagery (NRSA, 2006), is also used in regional applications (Bera et al. 2014; Das et al. 2015, 2018; Kumar and Gupta 2016), so we include this DSM in our assessments. The DSMs and DEMs evaluated are summarised in Table 2. 
Table 2: DEMs used in the study (adapted from Rexer \& Hirt, 2014)

\begin{tabular}{|c|c|c|c|c|c|}
\hline & $\begin{array}{l}\text { SRTM V3.0 } \\
\text { (S1) }\end{array}$ & $\begin{array}{c}\text { SRTM V4.1 } \\
\text { (S3) }\end{array}$ & $\begin{array}{c}\text { ASTER } \\
\text { GDEMV2 } \\
\text { (AS) }\end{array}$ & $\begin{array}{l}\text { Cartodem V2 } \\
\text { (CA) }\end{array}$ & $\begin{array}{l}\text { MERIT } \\
\text { (ME) }\end{array}$ \\
\hline Model type & DSM & DSM & DSM & DSM & DEM \\
\hline $\begin{array}{l}\text { Satellite } \\
\text { mission }\end{array}$ & $\begin{array}{l}\text { Shuttle Radar } \\
\text { Topography } \\
\text { Mission (SRTM) }\end{array}$ & SRTM & Terra & $\begin{array}{l}\text { Cartosat-1 } \\
\text { (NRSA, 2006) }\end{array}$ & $\begin{array}{l}\text { SRTM and } \\
\text { Advanced Land } \\
\text { Observing } \\
\text { Satellite (ALOS) }\end{array}$ \\
\hline Institution & NASA & CGIAR-CSI & METI, NASA & NRSC-ISRO & $\begin{array}{l}\text { Yamazaki et al. } \\
(2017)\end{array}$ \\
\hline $\begin{array}{l}\text { Resolution (in } \\
\text { arc seconds) }\end{array}$ & One & Three & One & One & Three \\
\hline Release year & 2015 & 2011 & 2011 & 2014 & 2018 \\
\hline Vertical datum & EGM96 & EGM96 & EGM96 & WGS84 & EGM96 \\
\hline Height type & Physical $^{1}$ & Physical & Physical & Ellipsoidal & Physical \\
\hline $\begin{array}{l}\text { Claimed } \\
\text { accuracy }\end{array}$ & $\begin{array}{l}16 \mathrm{~m} \text { at } 90 \% \\
\text { confidence, near- } \\
\text { global }\end{array}$ & $\begin{array}{l}16 \text { m at } 90 \% \\
\text { confidence, near- } \\
\text { global }\end{array}$ & $\begin{array}{l}17 \mathrm{~m} \text { at } 95 \% \\
\text { confidence, near- } \\
\text { global }\end{array}$ & $\begin{array}{l}8 \mathrm{~m} \text { at } 90 \% \\
\text { confidence, India- } \\
\text { only }\end{array}$ & $\begin{array}{l}12 \mathrm{~m} \text { at } 90 \% \\
\text { confidence, near- } \\
\text { global }\end{array}$ \\
\hline URL & $\begin{array}{l}\text { https://gdex.cr.us } \\
\text { gs.gov/gdex/ }\end{array}$ & $\begin{array}{l}\text { http://srtm.csi.cgi } \\
\text { ar.org/ }\end{array}$ & $\begin{array}{l}\text { https://search.eart } \\
\text { hdata.nasa.gov/ }\end{array}$ & $\begin{array}{l}\text { https://bhuvan- } \\
\text { app3.nrsc.gov.in/ } \\
\text { data/download/in } \\
\text { dex.php }\end{array}$ & $\begin{array}{l}\text { http://hydro.iis.u- } \\
\text { tokyo.ac.jp/ yam } \\
\text { adai/MERIT_DE } \\
\text { M/ }\end{array}$ \\
\hline
\end{tabular}

${ }^{1}$ By physical, we mean that the geometric ellipsoidal/geodetic height $(h)$ has been transformed to a physically meaningful orthometric height $(H)$ using a global geoid $(N)$ model $(H \approx h-N)$.

Due to the land height range in India $(-2 \mathrm{~m}$ to $+8586 \mathrm{~m})$, our analysis is broken down by classifying the heights into three intervals, with an implicit assumption that these may correlate with the broader morphology, namely $\mathrm{H} \leq 500 \mathrm{~m}, 500 \mathrm{~m}<\mathrm{H} \leq 1500 \mathrm{~m}$ and $\mathrm{H}>1500 \mathrm{~m}$ (Figure $2 \mathrm{~b}$ ). The rationale behind the chosen three intervals is: regions of the Gangetic plains, the Thar desert and the peninsular coastline are all below $500 \mathrm{~m}$; the whole of the Aravalli range (except a few peaks), the Vindhya range, majority of the Eastern Ghats and half of the Western Ghats are in between $500 \mathrm{~m}-1500 \mathrm{~m}$; while the other half of Western Ghats, a small extent of Eastern Ghats and almost whole of the Himalayan belt are above $1500 \mathrm{~m}$. The claimed accuracies/precisions for all the DEMs/DSMs (Table 2) are also cross-checked on whole-of-India and height-range-wise bases. This is of utility because the accuracy statistics defined from global assessments may not be applicable to India, which certainly appears to be the case for high-elevation areas.

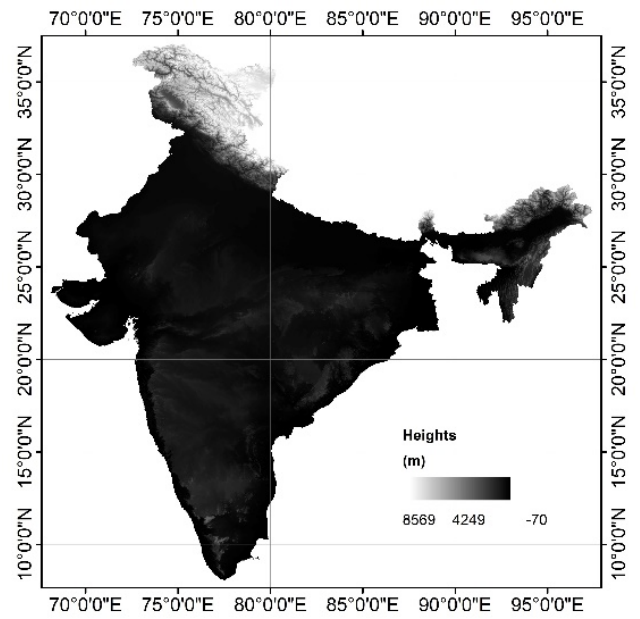

a)

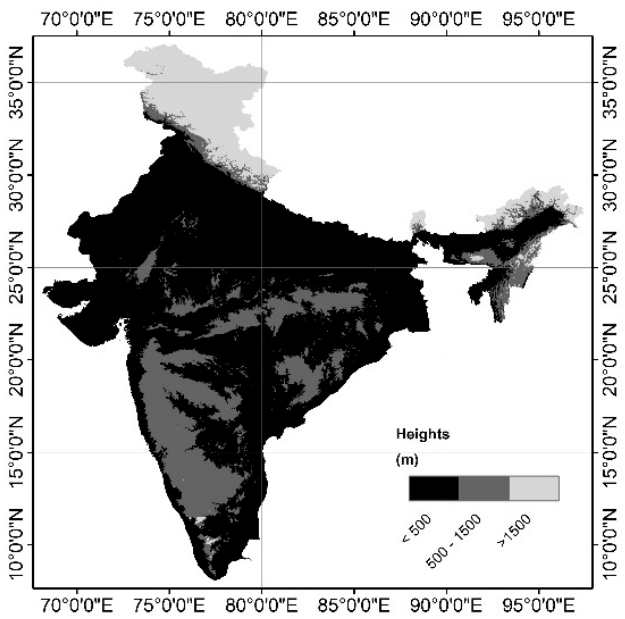

b)

Figure 2: The terrain of India (a) and the three height ranges tested (b) (equi-rectangular projection) 


\section{Subtleties of Indian height data}

The nominal vertical datum of the Cartodem DSM is WGS84 and it thus provides ellipsoidal heights of the Earth's surface. To achieve a consistent vertical datum among the DSMs (cf. Table 2), the Cartodem was also referenced to EGM96 (Lemoine et al. 1998) by subtracting EGM96 geoid undulation values and rounding to the nearest metre as was done when computing SRTM physical heights (cf. Farr et al. 2007, p.19). EGM96 is an older spherical harmonic degree-360 geopotential model, and comparatively better high-degree geopotential models are now available, such as EGM2008 to degree 2190 (Pavlis et al. 2012, 2013). To show the effect of using EGM2008 instead of EGM96, a difference map was prepared and truncated to the nearest metre. Figure 3 shows that DEMs/DSMs derived from each geoid model can differ by up to $12 \mathrm{~m}$ in magnitude, particularly in the Indian Himalaya (cf. Figure 1). The effect of the different geoid models will be assessed later in Section 3.3 .

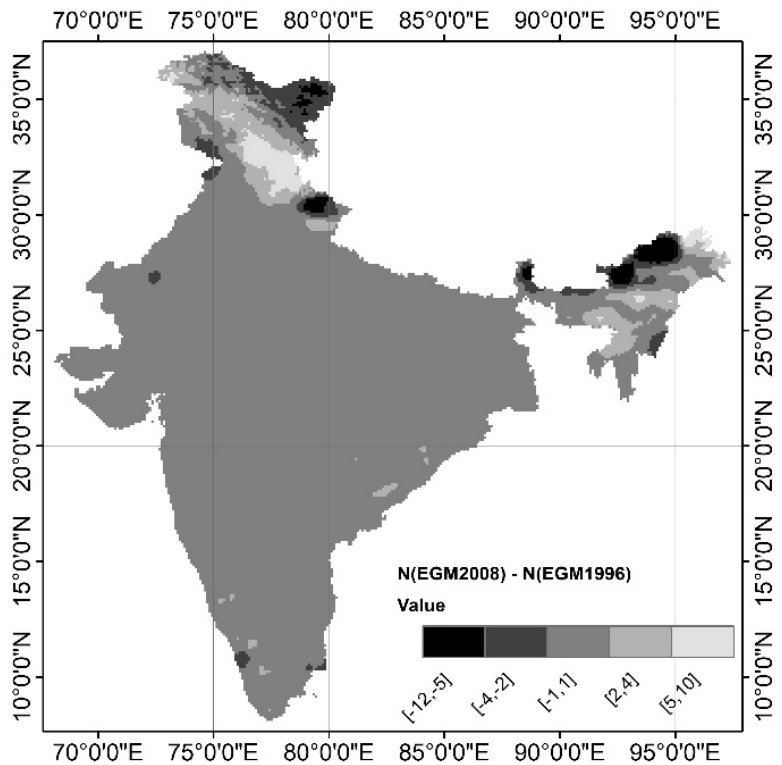

Figure 3: Geoid differences between EGM2008 and EGM96, truncated to the nearest metre (equi-rectangular projection)

As well as model-to-model comparisons, the DEMs/DSMs are "validated" with independent groundtruth data, comprising 3842 differentially levelled benchmarks and 145 ground control points (GCPs).

- The 3842 benchmarks (Figure 4) consist of latitude, longitude and levelled heights above local mean sea level (MSL). They come from the database archived by the Bureau Gravimetrique International (BGI), and were originally sourced from the SoI and the Indian National Geophysical Research Institute (NGRI). Though the horizontal and vertical precisions are not known, all the relevant infrastructure and research projects in India are based on benchmarks established by SoI. These are the heights that we have used in our analysis. Vertical precisions are important to be confident that we are not validating the DEM/DSM heights with erroneous ground control. Horizontal precision is important to be confident that we are not interpolating the DEM/DSM height to the wrong location, which can be a substantial problem in areas of steep terrain gradients.

- The 145 GCPs consist of GNSS-determined latitude, longitude and ellipsoidal height. Geoid undulation values from EGM96 were subtracted from these ellipsoidal heights to determine physical heights that are compatible with the DEMs/DSMs (cf. Table 2), but not rounded to the nearest metre. The GCPs are concentrated in five different regions of the country: Hyderabad, Bangalore, Kanpur, Dehradun and Saharanpur (Figure 5). The GCPs in Kanpur were observed using dual frequency GNSS while GCPs at other locations were obtained from the SoI archive. The horizontal and vertical precision of these data lie within $12 \mathrm{~mm}$ to $26 \mathrm{~mm}$ and $31 \mathrm{~mm}$ to $53 \mathrm{~mm}$, respectively (Mishra, 2017). 


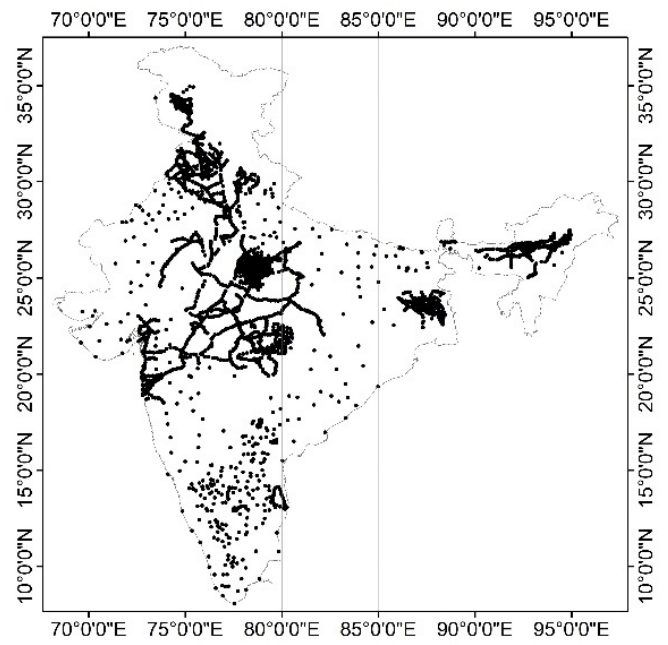

Figure 4: Spatial distribution of the 3842 levelled benchmarks (equi-rectangular projection)

We return to the caveat in the first paragraph of the Introduction, qualifying that a DEM is distinctly different from a DSM. The benchmarks and GCPs give the physical (MSL-based) heights of the solid ground, so are compatible with DEMs but not with DSMs. Therefore, in the later analysis (Section 4), canopy height $(\mathrm{CH})$ information is added to the ground-truth data for comparison with DSMs in order to achieve compatibility. We have not conducted an analysis of the veracity of the $\mathrm{CH}$ model over India, instead taking the published values "at face value". We also acknowledge that other corrections are needed, as outlined in the Introduction.

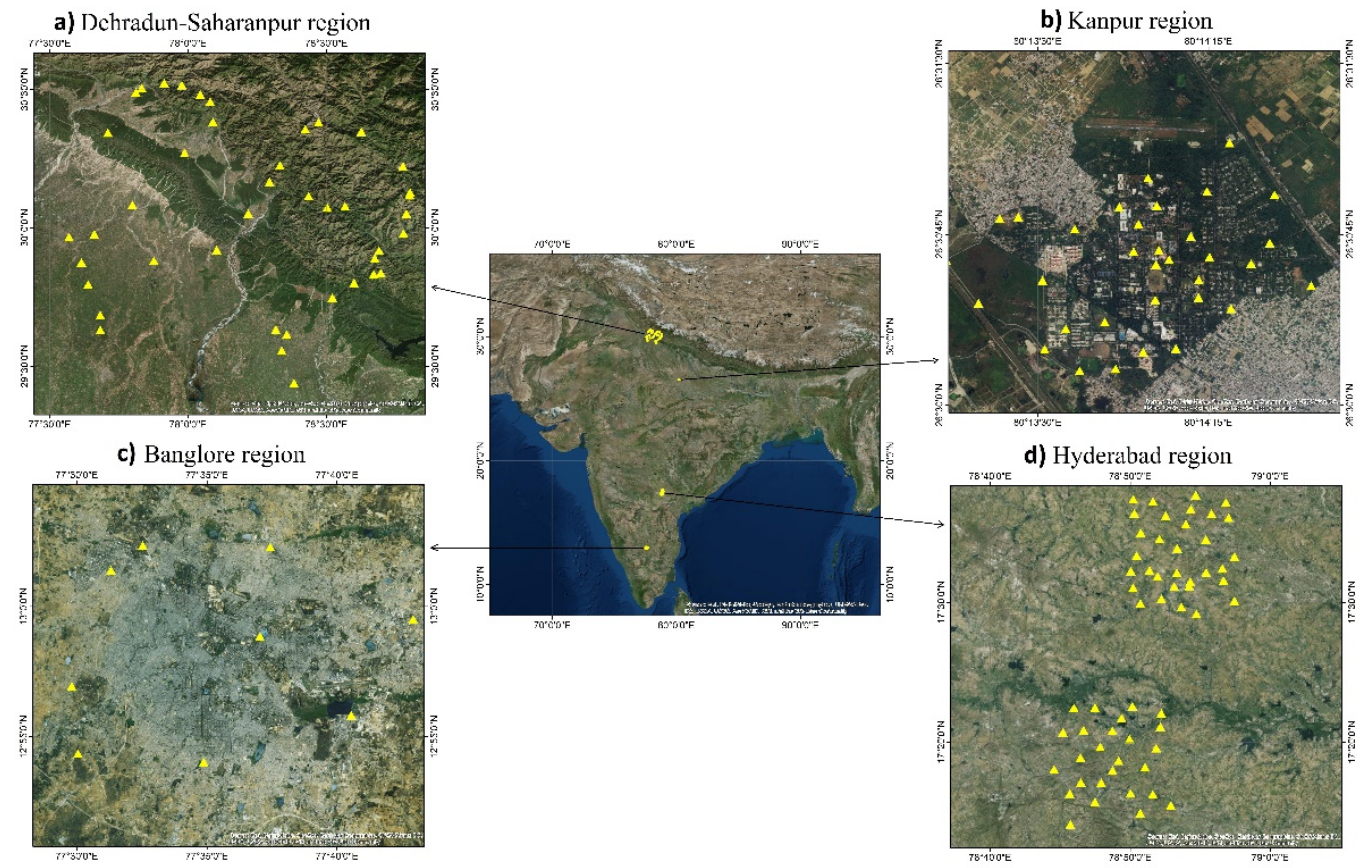

Figure 5: Spatial distribution of the 145 GCPs (source: Google Earth)

\section{Inter-comparison among DSMs}

The SRTM v4.1 DSM was first bicubically interpolated from 3"x3" to 1"x1" resolution to make it spatially consistent with the other three DSMs (SRTM v3.0, ASTER GDEM2 and Cartodem; Table 2). The DSMs were compared according to three criteria:

1. For the whole country of India, producing a total of 3,748,582,709 1"x1" DSM differences

2. For DSM heights divided into three ranges, namely $\mathrm{H} \leq 500 \mathrm{~m}, 500 \mathrm{~m}<\mathrm{H} \leq 1500 \mathrm{~m}$ and $\mathrm{H}>1500 \mathrm{~m}$ (Figure 2b)

3. For four intervals that are defined according to the claimed accuracies/precisions of the DSMs (Table 6 later). 
Finally, we replace EGM96 with EGM2008 for all the DSMs to gauge the effect of using a higher degree geoid model to obtain physical heights from a DSM.

\subsection{Nation-wide inter-comparison}

Possibly the most alarming observation from Table 3 is that the DSMs can differ by several kilometres, though the percentage of such pixels is proportionally small (Table 4). These large height differences among the DSMs are most probably due to geolocation errors (Rodriguez et al., 2005), i.e., horizontal shifts among the DSMs are caused by incorrect co-registration (Denker, 2004). These shifts result in comparing DEM/DSM cells of two different locations hence producing substantial height differences, especially in areas of steep terrain gradients. Also, from Table 4, the number of pixels in different ranges for S1-AS individually and S1-AS and AS-CA collectively show that SRTM1" and ASTER are more consistent with one other than the other model pairs. [The abbreviations for the DSM names are given in the first row of Table 2.] This consistency is also backed up by only $0.1 \%$ of the difference pixels for S1-AS lie beyond the range $[-100 \mathrm{~m}, 100 \mathrm{~m}]$. Also, on analysing the three pairs i.e., S1-AS, S3-CA and AS-CA, it is observed that the Cartodem, compared to SRTM3", have more congruency with SRTM1" and ASTER. This is probably only because SRTM3" was bicubically resampled to a 1"x1" spatial resolution. The total number of pixels in each DSM is 3,748,582,709 and $\triangle \mathrm{H}$ represents the difference among various pairs of DSMs (e.g., S1-S3, S1-AS, S1-CA, S3-AS, S3-CA and AS-CA).

Figure 6 shows the striping effects among the DSMs. Striping in ASTER was also observed by Hirt et al. (2010) over Australia. Considering the fact that SRTM have stripe effects with a different pattern compared to ASTER (cf. Gallant and Read, 2009), and on comparing i) Figures $6 \mathrm{~b}$ and c, and ii) Figures $6 \mathrm{~d}$ and e, it can be claimed that Cartodem also has the stripe effects that are nearly in the same direction as ASTER (Figures 6 $\mathrm{c}$ and e). Stripes are also seen in Figure $6 \mathrm{f}$ (AS-CA), indicating the non-negligible difference in the magnitude of the stripes in ASTER and Cartodem. Hirt et al. (2010) pointed out that the stripe effects in ASTER occur on scales of several thousand kilometres; Figure 6 shows the similarity of this phenomenon for Cartodem in India.

Table 3: Statistics of inter-comparison among DSMs. Units in metres.

The abbreviations for the DSM names are given in the first row of Table 2.

\begin{tabular}{|l|r|r|r|r|r|r|}
\hline & \multicolumn{1}{|c|}{ S1-S3 } & S1-AS & S1-CA & S3-AS & S3-CA & \multicolumn{1}{c|}{ AS-CA } \\
\hline Min & -4287 & -5815 & -4801 & -4363 & -5152 & -5859 \\
\hline Max & 5197 & 3109 & 3235 & 5792 & 4846 & 4295 \\
\hline Mean & 1.4 & 1.9 & -2.1 & -0.5 & 0.8 & -0.2 \\
\hline STD & 32.4 & 20.4 & 35.8 & 39.3 & 45.8 & 39.5 \\
\hline
\end{tabular}

Table 4: Distribution of 'large' differences among the DSMs over India.

The abbreviations for the DSM names are given in the first row of Table 2

\begin{tabular}{|c|c|c|c|c|c|c|c|}
\hline \multirow[t]{2}{*}{ Comparison } & \multicolumn{6}{|c|}{ Frequency of differences $(\Delta \mathrm{H})$ as a percentage } & \\
\hline & $\begin{array}{c}100 \mathrm{~m}<\Delta \mathrm{H} \\
\leq 500 \mathrm{~m}\end{array}$ & $\begin{array}{c}500 \mathrm{~m}< \\
\Delta \mathrm{H} \leq 1000 \\
\mathrm{~m}\end{array}$ & $\begin{array}{c}\Delta \mathrm{H}> \\
1000 \mathrm{~m}\end{array}$ & $\begin{array}{c}-100 \mathrm{~m}> \\
\Delta \mathrm{H} \geq-500 \\
\mathrm{~m}\end{array}$ & $\begin{array}{c}-500 \mathrm{~m}> \\
\Delta \mathrm{H} \geq- \\
1000 \mathrm{~m}\end{array}$ & $\begin{array}{l}\Delta \mathrm{H}<- \\
1000 \mathrm{~m}\end{array}$ & $\begin{array}{l}\text { Percentage } \\
\text { of total } \\
\text { number of } \\
\text { pixels }\end{array}$ \\
\hline S1 - S3 & 0.354 & 0.126 & 0.001 & 0.210 & 0.003 & 0.000 & 0.695 \\
\hline $\mathbf{S 1} \mathbf{A} \mathbf{A}$ & 0.023 & 0.001 & 0.000 & 0.035 & 0.012 & 0.009 & 0.080 \\
\hline S1 - CA & 0.313 & 0.059 & 0.013 & 0.473 & 0.036 & 0.007 & 0.901 \\
\hline $\mathbf{S 3}-\mathbf{A S}$ & 0.560 & 0.138 & 0.011 & 0.298 & 0.004 & 0.001 & 1.012 \\
\hline S3 - CA & 0.574 & 0.037 & 0.007 & 0.532 & 0.164 & 0.016 & 1.330 \\
\hline $\mathbf{A S}-\mathbf{C A}$ & 0.292 & 0.054 & 0.012 & 0.504 & 0.004 & 0.014 & 0.880 \\
\hline
\end{tabular}




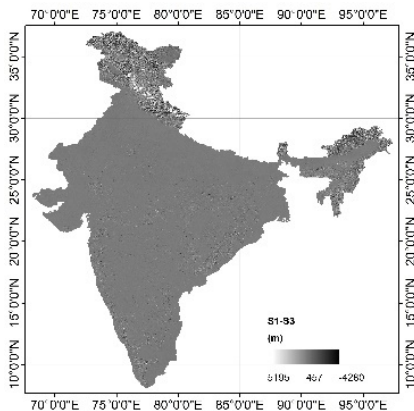

a)

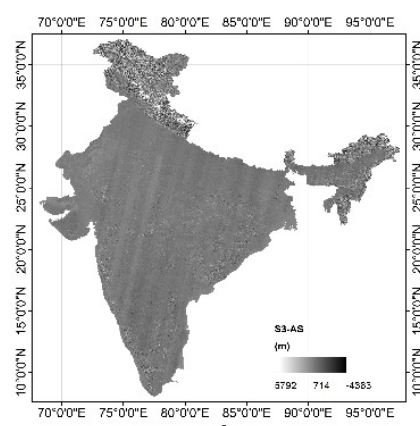

d)

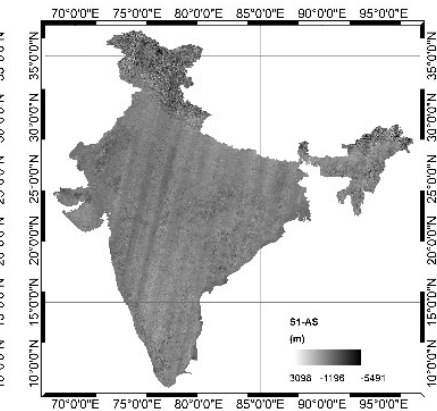

b)

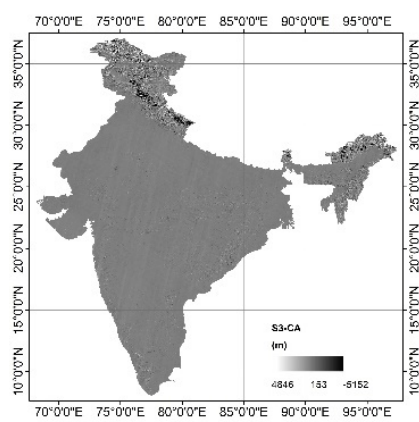

e)

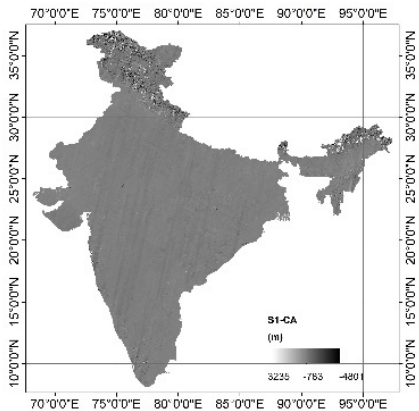

c)

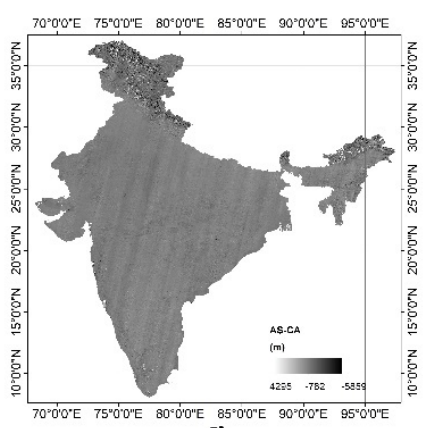

f)

Figure 6: Visual representation of the differences between DSM pairs over India, showing stripes.

[a) S1-S3; b) S1-AS; c) S1-CA; d) S3-AS; e) S3-CA; f) AS-CA].

The abbreviations for the DSM names are given in the first row of Table 2

\subsection{Height-range-wise inter-comparison}

Table 5 shows that, despite the lowest standard deviations (STDs) of $\Delta \mathrm{H}$ for the height range $\mathrm{H} \leq 500 \mathrm{~m}$, large differences exist among DSMs (cf. Table 4). The significant differences between S1-S3 (both derived from the same satellite mission) are possibly due to systematic errors between the two DSMs, primarily found in the mountainous regions. This is possibly because SRTM1", a high-resolution DSM, provides a better topographic representation compared to SRTM3", especially along ridges and valleys. Other discrepancies among Cartodem and other DSMs are also observed at the locations of large lakes and active open-pit mine-sites (Figure 7). This is due to the different epochs of the observations and re/processing involved in the development of eaach DSM, which is [partly] reflected by the release dates in Table 2. A similar observation has been reported by Long et al. (2020) over open-pit mines in Quang Ninh Province in Vietnam.

Table 5: Statistics of the DSM inter-comparison based on a range-wise classification.

Units in metres. The abbreviations for the DSM names are given in the first row of Table 2

\begin{tabular}{|l|l|r|r|r|r|r|r|}
\hline & & \multicolumn{1}{c|}{ S1-S3 } & \multicolumn{1}{c|}{ S1-AS } & \multicolumn{1}{c|}{ S1-CA } & \multicolumn{1}{c|}{ S3-AS } & \multicolumn{1}{c|}{ S3-CA } & AS-CA \\
\hline \multirow{4}{*}{ Min } & $\mathrm{H} \leq 500 \mathrm{~m}$ & -301 & -389 & -1026 & -326 & -5152 & -1180 \\
\cline { 2 - 8 } & $500 \mathrm{~m}<\mathrm{H} \leq 1500 \mathrm{~m}$ & -930 & -2490 & -685 & -969 & -2400 & -2390 \\
\cline { 2 - 8 } & $\mathrm{H}>1500 \mathrm{~m}$ & -4287 & -5815 & -4801 & -4363 & -5098 & -4295 \\
\hline \multirow{4}{*}{ Max } & $\mathrm{H} \leq 500 \mathrm{~m}$ & 5197 & 266 & 1189 & 5208 & 1034 & 1031 \\
\cline { 2 - 8 } & $500 \mathrm{~m}<\mathrm{H} \leq 1500 \mathrm{~m}$ & 1444 & 352 & 2397 & 2525 & 773 & 2578 \\
\cline { 2 - 8 } & $\mathrm{H}>1500 \mathrm{~m}$ & 5163 & 3109 & 3235 & 5792 & 4846 & 5859 \\
\hline \multirow{3}{*}{ Mean } & $\mathrm{H} \leq 500 \mathrm{~m}$ & 0.1 & 2.9 & -1.5 & -2.8 & 1.5 & -1.4 \\
\cline { 2 - 8 } & $500 \mathrm{~m}<\mathrm{H} \leq 1500 \mathrm{~m}$ & 0.3 & 3.1 & -1.5 & -2.8 & 1.2 & -1.6 \\
\cline { 2 - 8 } & $\mathrm{H}>1500 \mathrm{~m}$ & 11.0 & -5.8 & -6.7 & 16.9 & -4.3 & 12.5 \\
\hline \multirow{3}{*}{ STD } & $\mathrm{H} \leq 500 \mathrm{~m}$ & 5.7 & 6.9 & 6.9 & 9.5 & 8.2 & 10.11 \\
\cline { 2 - 8 } & $500 \mathrm{~m}<\mathrm{H} \leq 1500 \mathrm{~m}$ & 20.5 & 9.8 & 17.6 & 24.8 & 26.0 & 19.5 \\
\cline { 2 - 8 } & $\mathrm{H}>1500 \mathrm{~m}$ & 90.3 & 55.7 & 101.9 & 107.5 & 129.3 & 111.0 \\
\hline
\end{tabular}


a) Jayant, Chilkadand and Basi open pit mine site
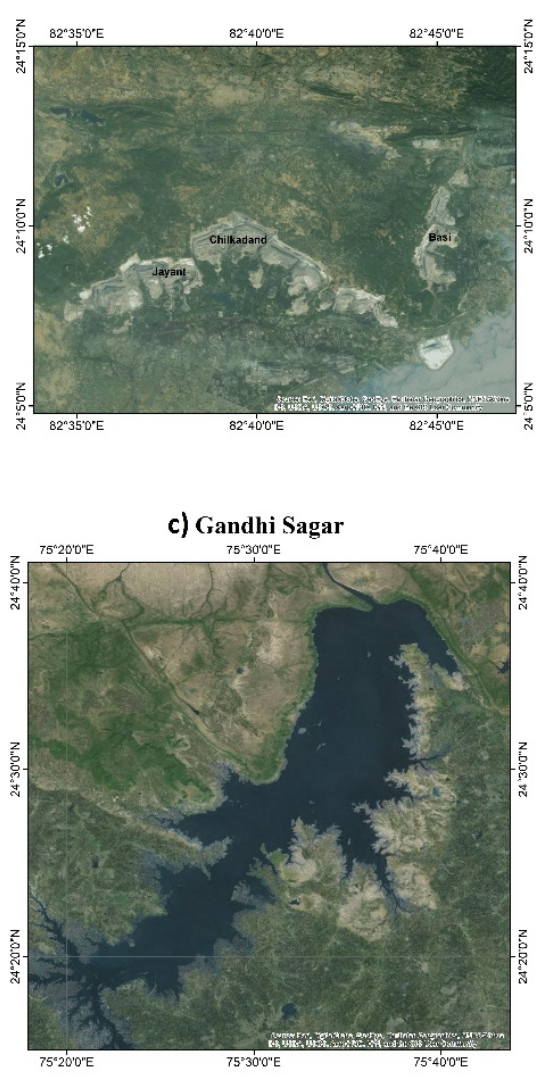

b) Jayant, Chilkadand and Basi open pit mine site

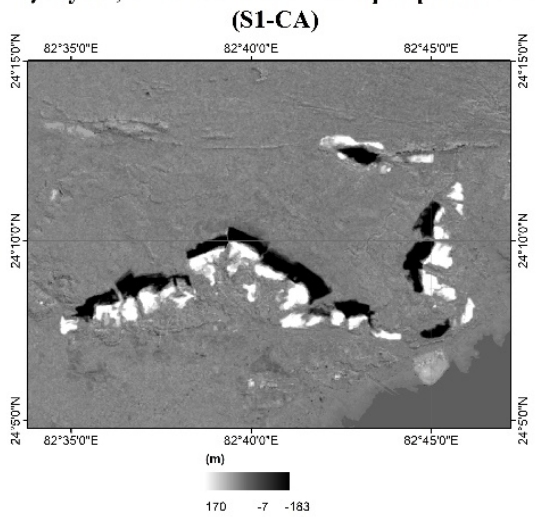

d) Gandhi Sagar (S1-CA)

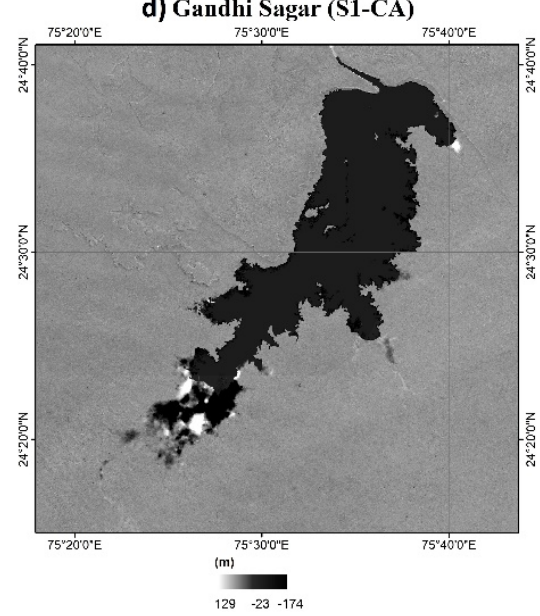

Figure 7: Differences between SRTM1" and Cartodem (grey-scale panels) at the locations of large lakes and active open-pit mine sites (background images from Google Earth).

\subsection{Inter-comparison according to DSM claimed precision}

We deduce four accuracy/precision intervals according to the claimed accuracies/precisions of the DSMs (Table 6). The percentages of points lying in these different intervals are shown in Table 7.

From Table 7, the percentages of pixels in intervals In1 and In2 for S1-AS, S3-AS and AS-CA show that ASTER contains more error compared to the other three DSMs. The claimed accuracies/precisions are only valid if $90 \%$ of the data satisfy the given accuracy requirements (cf. Rodriguez et al. 2005). In the lowland range $(<500 \mathrm{~m})$, more than $90 \%$ of the differences for S1-S3, S1-CA and S3-CA lie in the interval In2. This indicates that the three DSMs (i.e., S1, S3, CA) are congruous with their claimed accuracies, but only in this height range. It is found that $90 \%$ of the total S1-CA difference pixels (without any height-banded classification) fall within $\pm 8 \mathrm{~m}$, which resembles the observations of $90 \%$ by Muralikrishnan et al. (2013) and Bothale and Pandey (2013).

Finally, the overall statistics and the percentage of pixels in different accuracy/precision intervals after replacing EGM96 by EGM2008 for all the DSMs are summarised in Table 8. This shows no significant change either in the overall statistics (cf. Table 3) or the distribution of differences (cf. Table 7) after transforming the DSMs to physical heights using EGM2008. Therefore, it appears immaterial as to which geoid model is used to transform the geometric ellipsoidal heights to physical heights given the former's intrinsic accuracy/precision (cf. Figure 3), but this only applies to India and might not be the case in the countries with relatively lower topographical elevations. 
Table 6: Accuracy/precision intervals as deduced from other investigations

\begin{tabular}{|c|c|l|}
\hline Interval & $\begin{array}{c}\text { One Sigma Range } \\
(\mathbf{m})\end{array}$ & \multicolumn{1}{c|}{ Remarks } \\
\hline In1 & {$[-3.768,3.768]$} & $\begin{array}{l}\text { Rodriguez et al. (2005) computed an absolute height error of } 6.2 \mathrm{~m} \text { at } 90 \% \text { (1.645 } \mathrm{for} \\
\text { 1D) confidence in SRTM for Eurasia. Therefore, the first interval is taken as bounded } \\
\text { within } 6.2 / 1.645=3.768 \mathrm{~m}\end{array}$ \\
\hline In2 & {$[-9.726,9.726]$} & $\begin{array}{l}\text { One of the objectives of the SRTM mission was to obtain the absolute height error } \\
\text { within } 16 \mathrm{~m} \text { at } 90 \% \text { confidence (Farr et al. 2007). Therefore, the second interval is } \\
\text { taken as bounded within } 16 / 1.645=9.726 \mathrm{~m} . \\
\text { This bound also covers the accuracy estimate of Cartodem }(7.6 \mathrm{~m} \text { at } 90 \% \text { confidence, } \\
\text { i.e. } 4.62 \mathrm{~m} \text { (Rao et al. } 2014)) \text { and MERIT3" (12 } \mathrm{m} \text { at } 90 \% \text { confidence, i.e. } 7.29 \mathrm{~m} \\
\text { (Yamazaki et al. 2017)). }\end{array}$ \\
\hline In3 & {$[-16,16]$} & $\begin{array}{l}\text { This bound is chosen by hypothetically considering } 16 \mathrm{~m} \text { to be the } 1 \sigma \text { error bound in } \\
\text { the DSMs. }\end{array}$ \\
\hline In4 & ]$-16,16[$ & $\begin{array}{l}\text { This bound is to check the number of pixels that exceed the above hypothetical } 1 \sigma \\
\text { error bound in the DSMs. }\end{array}$ \\
\hline
\end{tabular}

Table 7: Percentage of pixels (from model-to-model comparison) lying in the intervals set in Table 6.

\begin{tabular}{|c|c|c|c|c|c|c|c|}
\hline & & S1-S3 & S1-AS & S1-CA & S3-AS & S3-CA & AS-CA \\
\hline \multirow{4}{*}{ In1 } & Overall & $69 \%$ & $34 \%$ & $62 \%$ & $30 \%$ & $56 \%$ & $37 \%$ \\
\hline & $\mathrm{H} \leq 500 \mathrm{~m}$ & $83 \%$ & $38 \%$ & $70 \%$ & $35 \%$ & $67 \%$ & $41 \%$ \\
\hline & $500 \mathrm{~m}<\mathrm{H} \leq 1500 \mathrm{~m}$ & $56 \%$ & $32 \%$ & $57 \%$ & $24 \%$ & $46 \%$ & $33 \%$ \\
\hline & $\mathrm{H}>1500 \mathrm{~m}$ & $14 \%$ & $16 \%$ & $23 \%$ & $8 \%$ & $11 \%$ & $12 \%$ \\
\hline \multirow{4}{*}{ In 2} & Overall & $84 \%$ & $75 \%$ & $91 \%$ & $67 \%$ & $83 \%$ & $76 \%$ \\
\hline & $\mathrm{H} \leq 500 \mathrm{~m}$ & $95 \%$ & $82 \%$ & $98 \%$ & $78 \%$ & $94 \%$ & $84 \%$ \\
\hline & $500 \mathrm{~m}<\mathrm{H} \leq 1500 \mathrm{~m}$ & $76 \%$ & $72 \%$ & $91 \%$ & $56 \%$ & $78 \%$ & $72 \%$ \\
\hline & $\mathrm{H}>1500 \mathrm{~m}$ & $29 \%$ & $42 \%$ & $52 \%$ & $20 \%$ & $27 \%$ & $32 \%$ \\
\hline \multirow{4}{*}{ In3 } & Overall & $89 \%$ & $92 \%$ & $95 \%$ & $83 \%$ & $89 \%$ & $90 \%$ \\
\hline & $\mathrm{H} \leq 500 \mathrm{~m}$ & $98 \%$ & $97 \%$ & $97 \%$ & $94 \%$ & $98 \%$ & $97 \%$ \\
\hline & $500 \mathrm{~m}<\mathrm{H} \leq 1500 \mathrm{~m}$ & $85 \%$ & $92 \%$ & $97 \%$ & $76 \%$ & $87 \%$ & $90 \%$ \\
\hline & $\mathrm{H}>1500 \mathrm{~m}$ & $43 \%$ & $64 \%$ & $69 \%$ & $33 \%$ & $42 \%$ & $51 \%$ \\
\hline \multirow{4}{*}{ In4 } & Overall & $11 \%$ & $8 \%$ & $4 \%$ & $17 \%$ & $11 \%$ & $10 \%$ \\
\hline & $\mathrm{H} \leq 500 \mathrm{~m}$ & $2 \%$ & $3 \%$ & $<1 \%$ & $6 \%$ & $2 \%$ & $3 \%$ \\
\hline & $500 \mathrm{~m}<\mathrm{H} \leq 1500 \mathrm{~m}$ & $15 \%$ & $8 \%$ & $3 \%$ & $24 \%$ & $13 \%$ & $10 \%$ \\
\hline & $\mathrm{H}>1500 \mathrm{~m}$ & $57 \%$ & $35 \%$ & $31 \%$ & $67 \%$ & $58 \%$ & $50 \%$ \\
\hline
\end{tabular}

Table 8: Statistics (cf. Table 3) and percentage of points in different intervals (cf. Table 6) after replacing EGM96 by EGM2008 geoid values. Units in metres.

\begin{tabular}{|l|r|r|r|r|r|r|}
\hline & S1-S3 & S1-AS & S1-CA & S3-AS & S3-CA & $\begin{array}{c}\text { AS- } \\
\text { CA }\end{array}$ \\
\hline Min & -4280 & -5810 & -4795 & -4356 & -5154 & -5864 \\
\hline Max & 5195 & 3116 & 3234 & 5797 & 4852 & 4288 \\
\hline Mean & 1.4 & 2.0 & -2.1 & -0.5 & 0.8 & 0.1 \\
\hline STD & 32.6 & 20.4 & 35.7 & 39.5 & 45.7 & 39.7 \\
\hline & & & & & & \\
\hline In1 & $69 \%$ & $34 \%$ & $61 \%$ & $29 \%$ & $56 \%$ & $36 \%$ \\
\hline In2 & $84 \%$ & $75 \%$ & $91 \%$ & $66 \%$ & $83 \%$ & $76 \%$ \\
\hline In3 & $89 \%$ & $92 \%$ & $95 \%$ & $83 \%$ & $89 \%$ & $90 \%$ \\
\hline In4 & $11 \%$ & $8 \%$ & $5 \%$ & $17 \%$ & $11 \%$ & $10 \%$ \\
\hline
\end{tabular}

\section{Validating DEMs with ground-truth physical heights}

The DEMs are now "validated" with two sets of independent ground-truth data: 3842 levelled benchmarks and 145 GPS-based GCPs. Recalling from Section 2, the ellipsoidal heights of GCPs were converted to physical heights by subtracting the EGM96 geoid model. Since SRTM1", SRTM3", ASTER and Cartodem are all DSMs, canopy height $(\mathrm{CH})$ data from NASA (Simard et al. 2011) were added to the ground-truth point heights. The $\mathrm{CH}$ data were not subtracted from the entire DSMs pixel-by-pixel because the conversion of a DSM to a DEM 
also involves extra filtering techniques as summarised in the Introduction. Thus, just removing the CHs does not necessarily provide a true DEM, but we believe it to be better than using a DSM alone. We did not conduct an analysis of the veracity of the $\mathrm{CH}$ data, instead taking the NASA model at face value.

Figure 8 shows the distribution of the heights of the 3842 benchmarks and 145 GCPs. They reflect the difficult logistics of collecting surveying data at inaccessible altitudes. As such, this validation only really holds for elevations less than, say, $\sim 500 \mathrm{~m}$ (cf. Figure 8a). In addition, the only sample geographically limited parts of India. Table 9 shows the statistics of comparisons between the DSMs/DEMs and these two ground-truth datasets, where the $\mathrm{CH}$ has been added when assessing the DSMs. For the heights extracted from Cartodem, there are two points with unexpectedly large height differences (i.e., $-191 \mathrm{~m}$ and $-186 \mathrm{~m}$ ). These points are not removed from the analyses because the overall statistics of the comparison after removing them does not change significantly $(\min =-336.7 \mathrm{~m}, \max =270.2 \mathrm{~m}$, mean $=0.9 \mathrm{~m}, \mathrm{MAE}=8.4 \mathrm{~m}, \mathrm{STD}=19.2 \mathrm{~m}$ and $\mathrm{RMSE}=$ $19.2 \mathrm{~m})$.
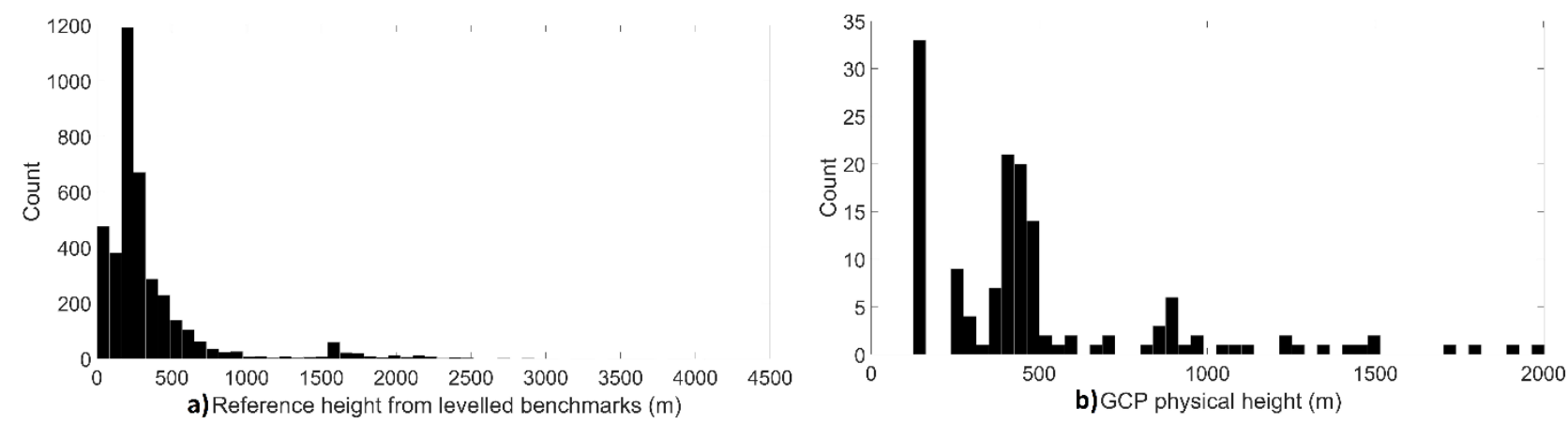

Figure 8: Distribution of the (a) levelled benchmark heights: $\max 4057.2 \mathrm{~m}$, $\min 1.5 \mathrm{~m}$, and (b) GCP heights: $\max 2002.7 \mathrm{~m}$, $\min 124.8 \mathrm{~m}$.

The statistics in Table 9, when viewed collectively and more so by the mean absolute error (MAE) and root mean square error (RMSE), indicate that MERIT3" compares relatively closer with respect to the groundtruth heights as compared to the DSMs. This is most probably because other error sources (mentioned in the Introduction) were removed in the construction of MERIT3" (Yamazaki et al. 2017), whereas we have only applied the CHs to the ground-truth in this study. The better results for MERIT3" with respect to the GCPs can also be attributed to GPS data generally being collected in open areas (away from buildings/trees) for satellite visibility. Therefore, there is less probability of $\mathrm{CH}$ error due to the presence of man-made features or vegetation (cf. Denker 2005; Hirt et al. 2010).

Table 9: Statistics of comparison between ground-truth heights and the DEMs/DSMs. Units in metres.

The abbreviations for the DSM names are given in the first row of Table 2

\begin{tabular}{|r|r|r|r|r|r|r|r|r|r|r|r|r|}
\hline & \multicolumn{5}{|c|}{3842 benchmarks } & \multicolumn{6}{|c|}{145 GCPs } \\
\hline & Min & Max & Mean & MAE & STD & $\begin{array}{r}\text { RMS } \\
\text { E }\end{array}$ & Min & Max & Mean & MAE & STD & $\begin{array}{l}\text { RMS } \\
\text { E }\end{array}$ \\
\hline S1 & 215.9 & 270.9 & 1.8 & 8.1 & 17.7 & 17.8 & -13.9 & 38.4 & 1.3 & 5.9 & 9.8 & 9.8 \\
\hline S3 & 220.9 & 257.5 & 1.9 & 8.0 & 17.2 & 17.3 & -49.3 & 102.4 & 2.1 & 8.1 & 17.5 & 17.6 \\
\hline AS & 212.9 & 243.9 & 4.4 & 10.5 & 18.8 & 19.3 & -21.2 & 43.9 & 5.4 & 8.2 & 10.0 & 11.4 \\
\hline CA & 336.7 & 270.2 & 1.0 & 8.5 & 19.7 & 19.7 & -11.4 & 50.2 & 1.9 & 5.7 & 9.4 & 9.6 \\
\hline ME & 256.3 & 249.9 & -0.4 & 7.1 & 17.3 & 17.3 & -33.4 & 24.3 & 0.7 & 4.5 & 7.1 & 7.1 \\
\hline
\end{tabular}

We next repeat the analyses conducted among the DSMs, but now with the ground-truth data, including the MERIT3" DEM, and after CHs have been added to the ground-truth when DSMs are assessed. We restrict the presentation here to only the levelled benchmarks because of the larger sample size with broader spatial (Figure 3) and vertical (Figure 8) distributions versus the GCPs (cf. Figures 4 and 8). Our analyses with the 
GCPs do not contradict the findings presented below. The DEM/DSM comparisons with height-range-wise and accuracy/precision-wise classification are given in Tables 10 and 11, respectively.

First, however, it is important to acknowledge that the number of benchmarks with MSL-based land elevations greater than $500 \mathrm{~m}$ is relatively few (Figure 8 and Table 10). As such, while all results are presented for the sake of completeness, lesser emphasis on the interpretation is made from them when $\mathrm{H}>500 \mathrm{~m}$. This is also demonstrated in Figure 9b-d, where the differences become more scattered for the higher elevation intervals. Figure 9a shows that all the differences are near-normally [Gaussian] distributed, hence justifying our use of descriptive statistics throughout this manuscript.

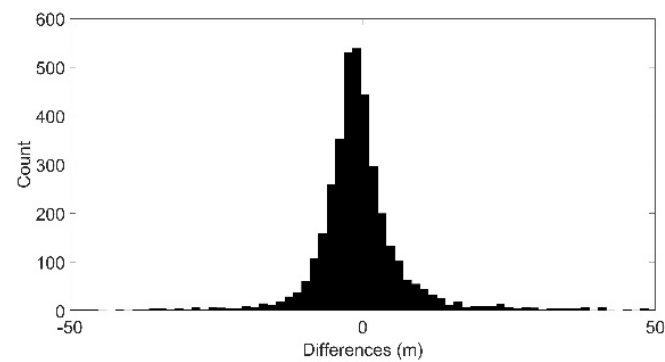

a)

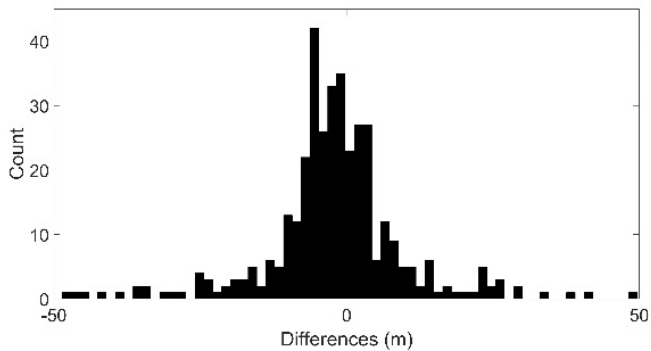

c)

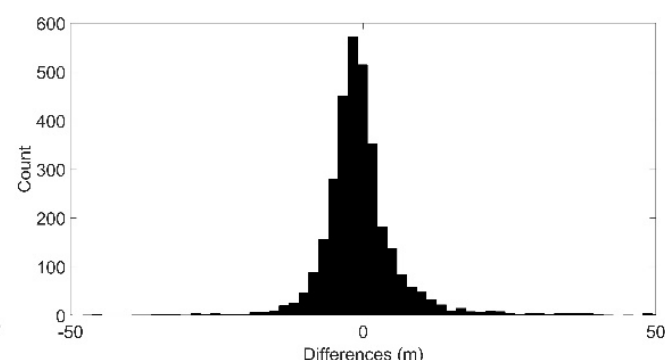

b)

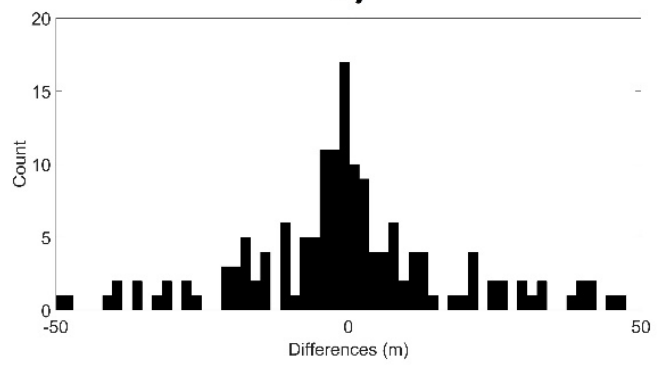

d)

Figure 9: Distributions of differences among benchmarks and the MERIT3" DEM for different intervals. a) all 3842 data points, b) 3278 points below $500 \mathrm{~m}$, c) 395 points between $500 \mathrm{~m}$ and $1500 \mathrm{~m}$, and d) 174 points above $1500 \mathrm{~m}$. Note the different $y$-axis scales.

Table 10: Statistics of the comparison with benchmarks based on range-wise classification. The model with the least MAE and RMSE values is the most preferred. Units in metres.

\begin{tabular}{|c|c|c|c|c|c|c|c|c|}
\hline & & \#data & Min & Max & Mean & MAE & STD & RMSE \\
\hline \multirow{5}{*}{$\mathrm{H} \leq 500 \mathrm{~m}$} & S1 & 3263 & -114.9 & 206.4 & 1.6 & 6.4 & 12.2 & 12.3 \\
\hline & S3 & 3263 & -118.6 & 206.4 & 1.6 & 6.3 & 12.0 & 12.1 \\
\hline & $\mathbf{A S}$ & 3263 & -107.9 & 210.4 & 4.5 & 8.8 & 13.6 & 14.3 \\
\hline & CA & 3263 & -336.7 & 204.5 & 0.6 & 6.7 & 14.5 & 14.5 \\
\hline & ME & 3273 & -128.6 & 207.4 & 0.0 & 5.5 & 11.7 & 11.7 \\
\hline \multirow{5}{*}{$500 \mathrm{~m}<\mathrm{H} \leq 1500 \mathrm{~m}$} & S1 & 403 & -215.9 & 243.5 & 2.6 & 14.1 & 28.8 & 28.9 \\
\hline & S3 & 403 & -220.9 & 257.5 & 2.1 & 14.9 & 30.0 & 30.1 \\
\hline & $\mathbf{A S}$ & 403 & -212.9 & 233.5 & 5.2 & 16.4 & 29.4 & 29.8 \\
\hline & CA & 403 & -216.5 & 246.5 & 2.5 & 14.6 & 30.4 & 30.4 \\
\hline & ME & 395 & -223.9 & 229.5 & -2.2 & 12.8 & 27.9 & 28.0 \\
\hline \multirow{5}{*}{$\mathrm{H}>1500 \mathrm{~m}$} & S1 & 176 & -209.3 & 270.9 & 3.7 & 25.9 & 47.1 & 47.1 \\
\hline & S3 & 176 & -119.4 & 181.9 & 7.2 & 24.4 & 41.0 & 41.5 \\
\hline & $\mathbf{A S}$ & 176 & -209.3 & 243.9 & 1.8 & 27.8 & 47.8 & 47.6 \\
\hline & $\mathbf{C A}$ & 176 & -290.7 & 270.2 & 5.9 & 27.3 & 49.1 & 49.3 \\
\hline & ME & 174 & -256.3 & 249.9 & -2.7 & 24.8 & 47.3 & 47.2 \\
\hline
\end{tabular}


Table 11: Percentage of points lying in different accuracy/precision intervals (cf. Table 6). The model with the highest percentage in intervals In1, In2, In3 and the lowest percentage in Interval In4 is the most preferred.

\begin{tabular}{|c|c|c|c|c|c|c|}
\hline & & S1 & $\overline{S 3}$ & $\overline{A S}$ & $\overline{\mathbf{C A}}$ & $\overline{M E}$ \\
\hline \multirow{4}{*}{ In1 } & Overall & $44 \%$ & $45 \%$ & $29 \%$ & $43 \%$ & $54 \%$ \\
\hline & $\mathrm{H} \leq 500 \mathrm{~m}$ & $48 \%$ & $48 \%$ & $31 \%$ & $47 \%$ & $58 \%$ \\
\hline & $500 \mathrm{~m}<\mathrm{H} \leq 1500 \mathrm{~m}$ & $27 \%$ & $28 \%$ & $23 \%$ & $29 \%$ & $37 \%$ \\
\hline & $\mathrm{H}>1500 \mathrm{~m}$ & $24 \%$ & $24 \%$ & $17 \%$ & $15 \%$ & $27 \%$ \\
\hline \multirow{4}{*}{ In 2} & Overall & $80 \%$ & $81 \%$ & $67 \%$ & $80 \%$ & $85 \%$ \\
\hline & $\mathrm{H} \leq 500 \mathrm{~m}$ & $84 \%$ & $86 \%$ & $70 \%$ & $84 \%$ & $89 \%$ \\
\hline & $500 \mathrm{~m}<\mathrm{H} \leq 1500 \mathrm{~m}$ & $65 \%$ & $63 \%$ & $50 \%$ & $63 \%$ & $72 \%$ \\
\hline & $\mathrm{H}>1500 \mathrm{~m}$ & $46 \%$ & $47 \%$ & $37 \%$ & $37 \%$ & $48 \%$ \\
\hline \multirow{4}{*}{ In3 } & Overall & $91 \%$ & $90 \%$ & $85 \%$ & $90 \%$ & $92 \%$ \\
\hline & $\mathrm{H} \leq 500 \mathrm{~m}$ & $94 \%$ & $94 \%$ & $89 \%$ & $94 \%$ & $95 \%$ \\
\hline & $500 \mathrm{~m}<\mathrm{H} \leq 1500 \mathrm{~m}$ & $80 \%$ & $80 \%$ & $71 \%$ & $78 \%$ & $81 \%$ \\
\hline & $\mathrm{H}>1500 \mathrm{~m}$ & $57 \%$ & $60 \%$ & $51 \%$ & $56 \%$ & $60 \%$ \\
\hline \multirow{4}{*}{ In4 } & Overall & $9 \%$ & $9 \%$ & $15 \%$ & $10 \%$ & $8 \%$ \\
\hline & $\mathrm{H} \leq 500 \mathrm{~m}$ & $6 \%$ & $6 \%$ & $11 \%$ & $6 \%$ & $5 \%$ \\
\hline & $500 \mathrm{~m}<\mathrm{H} \leq 1500 \mathrm{~m}$ & $20 \%$ & $22 \%$ & $29 \%$ & $22 \%$ & $18 \%$ \\
\hline & $\mathrm{H}>1500 \mathrm{~m}$ & $43 \%$ & $40 \%$ & $49 \%$ & $44 \%$ & $40 \%$ \\
\hline
\end{tabular}

With the data available to us, focussing on the $<500 \mathrm{~m}$ band in Table 10 shows that, despite the presence of large maximum and minimum differences, MERIT3" is more reliable, while Cartodem is less preferred among all the compared DEM/DSMs. The principal metrics used from Table 10 to make this inference are the MAE and RMSE. From the percentages in Table 11, no DEMs/DSMs have more than $90 \%$ points falling in the In1 or In2 intervals, which are defined based on the claimed DEM/DSM accuracies/precisions (cf. Table 6). In the $<500 \mathrm{~m}$ range only, however, all the DEMs/DSMs (except ASTER) have more than $90 \%$ of the points in the In 3 interval. ASTER provides the smallest percentage in the interval In 1 and the highest in In4, indicating it to be the least preferred DSM with respect to the ground-truth data in India. Thus, for the 1"x1" DSMs, SRTM1" and Cartodem appear more reliable as compared to ASTER over India. The MERIT3" DEM has the highest percentage of points in intervals In1, In 2 and In 3 and the lowest in In4, indicating to be most preferred among all the five models compared to the ground-truth benchmarks in India.

\section{Conclusions}

In this study, four freely available DSMs (SRTM1", SRTM3", ASTER1" and Cartodem1") along with the MERIT DEM developed by removing multiple error components from SRTM3 v2.1 are investigated based on a model-to-model comparison over the whole of India and a "validation" using ground-truth benchmark height data over some regions of India. Since India has varying topography (land heights range from $-2 \mathrm{~m}$ to $+8586 \mathrm{~m}$ ), the heights were divided into three ranges, namely $\mathrm{H} \leq 500 \mathrm{~m}, 500 \mathrm{~m}<\mathrm{H} \leq 1500 \mathrm{~m}$ and $\mathrm{H}>1500 \mathrm{~m}$. The percentage of points lying in the claimed accuracy/precision limits for different DEMs/DSMs were also analysed.

The model-to-model comparison among DSMs shows that SRTM1", SRTM3" and Cartodem are congruous with their claimed accuracy/precision, but only for heights less than $500 \mathrm{~m}$. Cartodem has the least discrepancies with SRTM1" compared to ASTER and SRTM3" in all three height ranges tested. There are artefacts between Cartodem and other DSMs due to time-varying heights in lakes and open-pit mining sites. Visual representation of the DSM differences confirmed that stripe effects are present in SRTM, ASTER and Cartodem over India, which appear to have been eliminated/reduced following the procedures involved in the production of MERIT3" (Yamazaki et al. 2017).

The validation with the only ground-truth data available to us shows that no DEMs/DSMs satisfy their claimed accuracies (intervals In1 and In2 in Table 6) in any height range. However, for elevations less than $500 \mathrm{~m}$ only, DEMs/DSMs (except ASTER) satisfy interval In3, but which is still beyond their claimed accuracies/precisions. The MERIT3" DEM is observed to be more reliable compared to the other DEMs/DSMs based on overall, range-wise and accuracy-wise analyses. However, this needs to be qualified by our use of only canopy heights to convert the ground-truth data to DSM-compatible heights. 


\section{References}

Ahmed, S.A., Chandrashekarappa, K.N., Raj, S.K., Nischitha, V., Kavitha, G., 2010. Evaluation of morphometric parameters derived from ASTER and SRTM DEM - a study on Bandihole sub-watershed basin in Karnataka. Journal of the Indian Society of Remote Sensing, 38(2), 227-238. https://doi.org/10.1007/s12524-010-0029-3.

Athmania, D., Achour, H., 2014. External validation of the ASTER GDEM2, GMTED2010 and CGIAR-CSI- SRTM v4.1 free access Digital Elevation Models (DEMs) in Tunisia and Algeria. Remote Sensing, 6(5), 4600-4620. https://doi.org/10.3390/rs6054600.

Banerjee, B., Gupta, S.P.D., 1977. Gravitational attraction of a rectangular parallelepiped. Geophysics, 42(5), 10531055. https://doi.org/10.1190/1.1440766.

Barnes, R., Lehman, C., Mulla, D., 2014. An efficient assignment of drainage direction over flat surfaces in raster digital elevation models. Computers \& Geosciences, 62, 128-135. https://doi.org/10.1016/j.cageo.2013.01.009.

Bera, A.K., Singh, V., Bankar, N., Salunkhe, S.S., Sharma, J.R., 2014. Watershed delineation in flat terrain of Thar desert region in North West India - A semi automated approach using DEM. Journal of the Indian Society of Remote Sensing, 42(1), 187-199. https://doi.org/10.1007/s12524-013-0308-x.

Berthier, E., Arnaud, Y., Kumar, R., Ahmad, S., Wagnon, P., Chevallier, P., 2007. Remote sensing estimates of glacier mass balances in the Himachal Pradesh (Western Himalaya, India). Remote Sensing of Environment, 108(3), 327338. https://doi.org/10.1016/j.rse.2006.11.017.

Bothale, R.V., Pandey, B., 2013. Evaluation and comparison of multi resolution DEM derived through Cartosat-1 stereo pair - a case study of Damanganga basin. Journal of the Indian Society of Remote Sensing 41(3), 497-507. https://doi.org/10.1007/s12524-012-0243-2.

Cavazzi, S., Corstanje, R., Mayr, T., Hannam, J., Fealy, R., 2013. Are fine resolution digital elevation models always the best choice in digital soil mapping? Geoderma, 195-196, 111-121. https://doi.org/10.1016/j.geoderma.2012.11.020.

Chirico, P.G., Malpeli, K.C., Trimble, S.M., 2012. Accuracy evaluation of an ASTER-derived Global Digital Elevation Model (GDEM) version 1 and version 2 for two sites in Western Africa. GIScience \& Remote Sensing, 49(6), 775801. https://doi.org/10.2747/1548-1603.49.6.775

Crippen, R., Buckley, S., Agram, P., Belz, E., Gurrola, E., Hensley, S., Kobrick, M., Lavalle, M., Martin, J., Neumann, M., Nguyen, Q., Rosen, P., Shimada, J., Simard, M., Tung, W., 2016. NASADEM global elevation model: methods and progress. ISPRS - International Archives of the Photogrammetry, Remote Sensing and Spatial Information Sciences, XLI-B4, 125-128. https://doi.org/10.5194/isprsarchives-XLI-B4-125-2016

Das, S., Kar, N.S., Bandyopadhyay, S., 2015. Glacial lake outburst flood at Kedarnath, Indian Himalaya: a study using digital elevation models and satellite images. Natural Hazards, 77(2), 769-786. https://doi.org/10.1007/s11069-0151629-6.

Das, S., Pardeshi, S.D., Kulkarni, P.P., Doke, A., 2018. Extraction of lineaments from different azimuth angles using geospatial techniques: a case study of Pravara basin, Maharashtra, India. Arabian Journal of Geosciences, 11(8), 160. https://doi.org/10.1007/s12517-018-3522-6.

Demirkesen, A.C., 2012. Multi-risk interpretation of natural hazards for settlements of the Hatay province in the east Mediterranean region, Turkey using SRTM DEM. Environmental Earth Sciences, 65(6), 1895-1907. https://doi.org/10.1007/s12665-011-1171-0.

Denker, H., 2005. Evaluation of SRTM3 and GTOPO30 terrain data in Germany. in: Jekeli C., Bastos L., \& Fernandes J. (Eds.), Gravity, geoid and space missions. IAG International Symposium, vol 129, pp. 218-223. Springer, Heidelberg. https://doi.org/10.1007/3-540-26932-0_38.

Dobos, E., Hengl, T., 2009. Soil mapping applications. in: Hengl. T., \& Reuter, H. I. (Eds.), Geomorphometry: concepts, software, applications. Developments in soil science, vol 33, pp. 461-480. Elsevier, Amsterdam.

Elkhrachy, I., 2018. Vertical accuracy assessment for SRTM and ASTER Digital Elevation Models: a case study of Najran city, Saudi Arabia. Ain Shams Engineering Journal, 9(4), 1807-1817. https://doi.org/10.1016/j.asej.2017.01.007.

Farr, T.G., Rosen, P.A., Caro, E., Crippen, R., Duren, R., Hensley, S., Kobrick, M., Paller, M., Rodriguez, E., Roth, L., Seal, D., Shaffer, S., Shimada, J., Umland, J., Werner, M., Oskin, M., Burbank, D., Alsdorf, D., 2007. The Shuttle Radar Topography Mission. Reviews of Geophysics, 45(2), RG2004. https://doi.org/10.1029/2005RG000183

Forsberg, R., 1984. Study of terrain reductions, density anomalies and geophysical inversion methods in gravity field modelling. Report 355, Department of Geodetic Science and Surveying, The Ohio State University, Columbus, USA.

Gallant, J., 2011. Adaptive smoothing for noise DEMs. in: Hengl, T. (ed.) Proceedings of Geomorphometry 2011, pp. 37-40. Redlands, California.

Gallant, J.C., Read, A., 2009. Enhancing the SRTM data for Australia. In: Proceedings of Geomorphometry, 31, pp. 149154.

Gayen, S., Bhunia, S.G., Shit, P.V., 2013. Morphometric analysis of Kangshabati-Darkeswar interfluves area in West Bengal, India using ASTER DEM and GIS techniques. Journal of Geology \& Geosciences, 02(04), 1000133. https://doi.org/10.4172/2329-6755.1000133. 
Gesch, D.B., 2012. Global digital elevation model development from satellite remote-sensing data. in: Yang, X., \& Li., J. (eds.), Advances in mapping from remote sensor imagery: techniques and applications, pp. 91-117. CRC press, Boca Raton, Florida.

Gesch, D.B., Oimoen, M.J., Evans, G.A., 2014. Accuracy assessment of the U.S. geological survey national elevation dataset, and comparison with other large-area elevation datasets-SRTM and ASTER. Open file report 2014-1008. U.S. Geological Survey, Reston, Virginia.

Gesch, D., Oimoen, M., Zhang, Z., Meyer, D., Danielson, J., 2012. Validation of the aster global digital elevation model version 2 over the conterminous United States. International Archives of the Photogrammetry, Remote Sensing and Spatial Information Sciences, XXXIX(B4), 281-286. https://doi.org/ 10.5194/isprsarchives-XXXIX-B4-281-2012.

Gopinath, G., Swetha, T.V., Ashitha, M.K., 2014. Automated extraction of watershed boundary and drainage network from SRTM and comparison with Survey of India toposheet. Arabian Journal of Geosciences, 7(7), 2625-2632. https://doi.org/10.1007/s12517-013-0919-0.

Gruber, S., Huggel, C., Pike, R., 2009. Modelling mass movements and landslide susceptibility. in: Hengl, T., \& Reuter, H. I. (Eds.), Geomorphometry: concepts, software, applications. Developments in soil science, vol 33, pp. 527-550. Elsevier, Amsterdam.

Hawker, L., Neal, J., Bates, P., 2019. Accuracy assessment of the TanDEM-X 90 Digital Elevation Model for selected floodplain sites. Remote Sensing of Environment, 232, 111319. https://doi.org/10.1016/j.rse.2019.111319

Hayakawa, Y.S., Oguchi, T., Lin, Z., 2008. Comparison of new and existing global digital elevation models: ASTER GDEM and SRTM-3. Geophysical Research Letters, 35(17), L17404. https://doi.org/10.1029/2008GL035036.

Hilton, R.D., Featherstone, W.E., Berry, P.A.M., Johnston, C.P.D., Kirby, J. F., 2003. Comparison of digital elevation models over Australia and external validation using ERS-1 satellite radar altimetry. Australian Journal of Earth Sciences, 50, 157-168. https://doi.org/10.1046/j.1440-0952.2003.00982.x

Hirt, C., 2014. Digital Terrain Models. in: Grafarend, E. (ed.), Encyclopedia of Geodesy, pp. 16. https://doi.org/10.1007/978-3-319-02370-0_31-1.

Hirt, C., 2018. Artefact detection in global digital elevation models (DEMs): The maximum slope approach and its application for complete screening of the SRTM v4.1 and MERIT DEMs. Remote Sensing of Environment, 207, 2741. https://doi.org/10.1016/j.rse.2017.12.037.

Hirt, C., Filmer, M.S., Featherstone, W.E., 2010. Comparison and validation of the recent freely available ASTERGDEM ver1, SRTM ver4.1 and GEODATA DEM-9S ver3 digital elevation models over Australia. Australian Journal of Earth Sciences, 57(3), 337-347. https://doi.org/10.1080/08120091003677553.

Ioannidis, C., Xinogalas, E., Soile, S., 2014. Assessment of the global digital elevation models ASTER and SRTM in Greece. Survey Review, 46(338), 342-354. https://doi.org/10.1179/1752270614Y.0000000114.

Jafarzadegan, K., Merwade, V., 2017. A DEM-based approach for large-scale floodplain mapping in ungauged watersheds. Journal of Hydrology, 550, 650-662. https://doi.org/10.1016/j.jhydrol.2017.04.053.

Jing, C., Shortridge, A., Lin, S., Wu, J., 2014. Comparison and validation of SRTM and ASTER GDEM for a subtropical landscape in Southeastern China. International Journal of Digital Earth, 7(12), 969-992. https://doi.org/10.1080/17538947.2013.807307.

Krishnan, S., Sajikumar, N., Sumam, K.S., 2016. DEM generation using Cartosat-I stereo data and its comparison with publically available DEM. Procedia Technology, 24, 295-302. https://doi.org/10.1016/j.protcy.2016.05.039.

Kumar, A., Chingkhei, R.K., Dolendro, T., 2007. Tsunami damage assessment: a case study in Car Nicobar Island, India. International Journal of Remote Sensing, 28(13-14), 2937-2959. https://doi.org/10.1080/01431160601091852.

Kumar, S., Gupta, S., 2016. Geospatial approach in mapping soil erodibility using CartoDEM - a case study in hilly watershed of lower Himalayan range. Journal of Earth System Science, 125(7), 1463-1472. https://doi.org/10.1007/s12040-016-0738-2.

Lemoine, F.G., Kenyon, S.C., Factor, J.K., Trimmer, R.G., Pavlis, N.K., Chinn, D.S., Cox, C.M., Klosko, S.M., Luthcke, S.B., Torrence, M.H., Wand, Y.M.m Williamson, R.G., Pavlis, E.C., Rapp, R.H., Olson, T. R., 1998. The development of the joint NASA GSFC and the National Imagery and Mapping Agency (NIMA) Geopotential Model EGM96, NASA/TP-1998-206861. National Aeronautics and Space Administration, Greenbelt.

Li, C., Wang, Y., Ye, C., Wei, W., Zheng, B., Xu, B., 2019. A proposed delineation method for lake buffer zones in watersheds dominated by non-point source pollution. Science of The Total Environment, 660, 32-39. https://doi.org/10.1016/j.scitotenv.2018.12.468.

Li, P., Shi, C., Li, Z., Muller, J.-P., Drummond, J., Li, X., Li, T., Li, Y., Liu, J., 2013. Evaluation of ASTER GDEM using GPS benchmarks and SRTM in China. International Journal of Remote Sensing, 34(5), 1744-1771. https://doi.org/10.1080/01431161.2012.726752.

Long N.Q., Goyal R., Bui L.K., Bui X.N., 2020. Assessment of Global Digital Height Models over Quang Ninh Province, Vietnam. In: Bui X.N., Lee C., Drebenstedt C. (eds) Proceedings of the International Conference on Innovations for Sustainable and Responsible Mining. Lecture Notes in Civil Engineering, vol 109, pp. 1-12. Springer, Cham. https://doi.org/10.1007/978-3-030-60839-2_1

Meyer, D., Tachikawa, T., Kaku, M., Iwasaki, A., Gesch, D., Oimoen, M., Zhang, Z., Danielson, J., Krieger, T., Curtis, B., Haase, J., Abrams, M., Crippen, R., Carabajal, C., 2011. ASTER global digital elevation model version 2- 
summary of validation results. Available at:

https://ssl.jspacesystems.or.jp/ersdac/GDEM/ver2Validation/Summary_GDEM2_validation_report_final.pdf.

Mishra, U. N., 2017. A comparative evaluation of methods for development of Indian geoid model. PhD Thesis. Indian Institute of Technology Roorkee, India.

Mukul, M., Srivastava, V., Jade, S., Mukul, M., 2017. Uncertainties in the Shuttle Radar Topography Mission (SRTM) heights: insights from the Indian Himalaya and Peninsula. Scientific Reports, 7(1), 41672. https://doi.org/10.1038/srep41672.

Muralikrishnan, S., Pillai, A., Narender, B., Reddy, S., Venkataraman, V.R., Dadhwal, V.K., 2013. Validation of Indian national DEM from Cartosat-1 data. Journal of the Indian Society of Remote Sensing, 41(1), 1-13. https://doi.org/10.1007/s12524-012-0212-9.

Nardi, F., Annis, A., Di Baldassarre, G., Vivoni, E.R., Grimaldi, S., 2019. GFPLAIN250m, a global high-resolution dataset of Earth's floodplains. Scientific Data, 6, 180309. https://doi.org/10.1038/sdata.2018.309.

Nikolakopoulos, K.G., Kamaratakis, E.K., Chrysoulakis, N., 2006. SRTM vs ASTER elevation products. Comparison for two regions in Crete, Greece. International Journal of Remote Sensing, 27(21), 4819-4838. https://doi.org/10.1080/01431160600835853.

NRSA, 2006. CARTOSAT-1 data user's handbook. National Remote Sensing Agency, India, Technical Report CARTOSAT-1/NRSA/NDC/HB-09/06.

O’Loughlin, F.E., Paiva, R.C.D., Durand, M., Alsdorf, D.E., Bates, P.D., 2016. A multi-sensor approach towards a global vegetation corrected SRTM DEM product. Remote Sensing of Environment, 182, 49-59. https://doi.org/10.1016/j.rse.2016.04.018.

Park, S., Oh, C., Jeon, S., Jung, H., Choi, C., 2011. Soil erosion risk in Korean watersheds, assessed using the revised universal soil loss equation. Journal of Hydrology, 399(3-4), 263-273. https://doi.org/10.1016/j.jhydrol.2011.01.004.

Patro, S., Chatterjee, C., Singh, R., Raghuwanshi, N.S., 2009. Hydrodynamic modelling of a large flood-prone river system in India with limited data. Hydrological Processes, 23(19), 2774-2791. https://doi.org/10.1002/hyp.7375.

Pavlis, N.K., Holmes, S.A., Kenyon, S.C., Factor, J.K., 2012. The development and evaluation of the Earth Gravitational Model 2008 (EGM2008). Journal of Geophysical Research: Solid Earth, 118(5), 2633-2633. https://doi.org/10.1002/jgrb.50167.

Pavlis, N.K., Holmes, S.A., Kenyon, S.C., Factor, J.K., 2013. Correction to "the development and evaluation of the Earth Gravitational Model 2008 (EGM2008)". Journal of Geophysical Research: Solid Earth, 117(B4), B04406. https://doi.org/10.1029/2011JB008916.

Purinton, B., Bookhagen, B., 2017. Validation of digital elevation models (DEMs) and comparison of geomorphic metrics on the southern Central Andean Plateau. Earth Surface Dynamics, 5(2), 211-237. https://doi.org/10.5194/esurf-5-211-2017.

Racoviteanu, A.E., Manley, W.F., Arnaud, Y., Williams, M.W., 2007. Evaluating digital elevation models for glaciologic applications: an example from Nevado Coropuna, Peruvian Andes. Global and Planetary Change, 59(1-4), 110-125. https://doi.org/10.1016/j.gloplacha.2006.11.036.

Ramakrishnan, D., Bandyopadhyay, A., Kusuma, K.N., 2009. SCS-CN and GIS-based approach for identifying potential water harvesting sites in the Kali Watershed, Mahi River Basin, India. Journal of Earth System Science, 118(4), 355368. https://doi.org/10.1007/s12040-009-0034-5.

Rao, S.P., Murthy, K.S., Kumar, P.A., 2014. Evaluation of Indian national DEM (Version-2) from Cartosat-1 data. National Remote Sensing Center, Indian Space Research Organisation, Hyderabad India, Technical Report NRSCSDAPSA-Dec 2014-TR-697.

Rawat, K.S., Singh, S.K., Singh, M.I., Garg, B.L., 2019. Comparative evaluation of vertical accuracy of elevated points with ground control points from ASTERDEM and SRTMDEM with respect to CARTOSAT-1DEM. Remote Sensing Applications: Society and Environment. 13, 289-297. https://doi.org/10.1016/j.rsase.2018.11.005.

Rexer, M., Hirt, C., 2014. Comparison of free high resolution digital elevation data sets (ASTER GDEM2, SRTM v2.1/v4.1) and validation against accurate heights from the Australian National Gravity Database. Australian Journal of Earth Sciences, 61(2), 213-226. https://doi.org/10.1080/08120099.2014.884983.

Rodriguez, E., Morris, C.S., Belz, J.E., Chapin, E.C., Martin, J.M., Daffer, W., Hensley, S., 2005. An assessment of the SRTM topographic products. Jet Propulsion Laboratory, Pasadena, Technical Report JPL D-31639.

Selvan, M.T., Ahmad, S., Rashid, S.M., 2011. Analysis of the geomorphometric parameters in high altitude glacierised terrain using SRTM DEM data in Central Himalaya, India. ARPN Journal of Science and Technology, 1(1), 22-27.

Simard, M., Pinto, N., Fisher, J.B., Baccini A., 2011. Mapping forest canopy height globally with spaceborne lidar. Journal of Geophysical Research, 116(G4), G04021. https://doi.org/10.1029/2011JG001708.

Sreedevi, P.D., Owais, S., Khan, H.H., Ahmed, S., 2009. Morphometric analysis of a watershed of south India using SRTM data and GIS. Journal of the Geological Society of India, 73(4), 543-552. https://doi.org/10.1007/s12594-0090038-4.

Srivastava, V.K., Mondal, K., 2012. Evaluation of Digital Elevation Models (DEMs) generated from ASTER and SRTM data: a case study of flat alluvium terrain of Bakreshwar-Dubrajpur (W.B.), India. in: Proceedings of $1^{\text {st }}$ International 
Conference on Recent Advances in Information Technology, pp. 666-671. Dhanbad, India. https://doi.org/10.1109/RAIT.2012.6194609.

Suwandana, E., Kawamura, K., Sakuno, Y., Kustiyanto, E., Raharjo, B., 2012. Evaluation of ASTER GDEM2 in comparison with GDEM1, SRTM DEM and topographic-map-derived DEM using inundation area analysis and RTKDGPS data. Remote Sensing, 4(8), 2419-2431. https://doi.org/10.3390/rs4082419.

Tarekegn, T.H., Sayama, T., 2013. Correction of SRTM dem artefacts by fourier transform for flood inundation modeling. Journal of Japan Society of Civil Engineers, Ser. B1 (Hydraulic Engineering), 69(4), I_193I_198. https://doi.org/10.2208/jscejhe.69.I_193.

Thomas, J., Prasannakumar, V., Vineetha, P., 2015. Suitability of spaceborne digital elevation models of different scales in topographic analysis: an example from Kerala, India. Environmental Earth Sciences, 73(3), 1245-1263. https://doi.org/10.1007/s12665-014-3478-0.

Truhetz, H., 2010. High resolution wind field modelling over complex topography analysis and future scenarios. PhD Thesis, Wegener Center for Climate and Global Change, University of Graz, Graz, Austria.

Varga, M., Bašić, T., 2015. Accuracy validation and comparison of global digital elevation models over Croatia. International Journal of Remote Sensing, 36(1), 170-189. https://doi.org/10.1080/01431161.2014.994720.

Yadav, S., Indu, J., 2016. Estimation of vertical accuracy of Digital Elevation Models over complex terrains of Indian subcontinent. in: 2016 IEEE International Geoscience and Remote Sensing Symposium, pp. 6036-6039. https://doi.org/10.1109/IGARSS.2016.7730577.

Yamazaki, D., Ikeshima, D., Tawatari, R., Yamaguchi, T., O’Loughlin, F., Neal, J.C., Sampson, C.C., Kanae, S., Bates, P.D., 2017. A high-accuracy map of global terrain elevations. Geophysical Research Letters, 44(11), 5844-5853. https://doi.org/10.1002/2017GL072874.

Yang, M., Hirt, C., Rexer, M., Pail, R., Yamazaki, D., 2019. The tree-canopy effect in gravity forward modelling. Geophysical Journal International, 219(1), 271-289. https://doi.org/10.1093/gji/ggz264.

Zhang, K., Gann, D., Ross, M., Robertson, Q., Sarmiento, J., Santana, S., Rhome, J., Fritz, C., 2019. Accuracy assessment of ASTER, SRTM, ALOS, and TDX DEMs for Hispaniola and implications for mapping vulnerability to coastal flooding. Remote Sensing of Environment, 225, 290-306. https://doi.org/10.1016/j.rse.2019.02.028.

Zhao, Y., Wu, P., Li, J., Lin, Q., Lu, Y., 2019. A new algorithm for the automatic extraction of valley floor width. Geomorphology, 335, 37-47. https://doi.org/10.1016/j.geomorph.2019.03.015. 